\title{
Test Plan for Effect of Phase Separation on Optimization of Waste Loading in High-Level Waste
}

by

C. M. Jantzen

Westinghouse Savannah River Company

Savannah River Site

Aiken, South Carolina 29808

R. L. Schulz

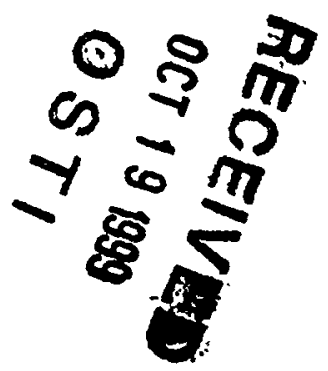

DOE Contract No. DE-AC09-96SR18500

This paper was prepared in connection with work done under the above contract number with the U. S. Department of Energy. By acceptance of this paper, the publisher and/or recipient acknowledges the U. S. Government's right to retain a nonexclusive, royalty-free license in and to any copyright covering this paper, along with the right to reproduce and to authorize others to reproduce all or part of the copyrighted paper. 
Keywords: waste glass, phase separation, glass durability, glass quality

TEST PLAN,FOR EFFECT OF PHASE SEPARATION ON OPTIMIZATION OF WASTE LOADING IN HIGH LEVEL WASTE GLASSES (U)

C. M. JANTZEN and R. L. SCHULZ

Westinghouse Savannah River Technology Center Aiken, SC 29808

Prepared for:

Tank Waste Focus Area

TTP\# AE1-6-WT-31

Subtask A.2

Milestone A.2-4

Approved by:

E.W. Holtzscheiter, Research Manager

Defense Waste Processing Technology

Publication Date: April 1, 1999

Westinghouse Savannah River Co.

Savannah River Site

Aiken, SC 29808

PREPARED FOR THE U.S. DEPARTMENT OF ENERGY UNDER CONTRACT DE-AC09-89SR18035

Westinghouse Savannah River Company

Savannah River Site

Aiken, SC 29808

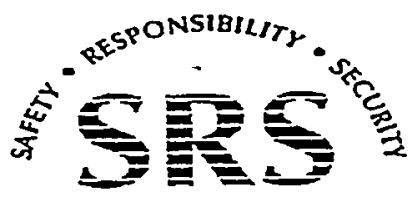

PREPARED FOR TIE U.S. DEPARTMENT OF ENERGY UNDER CONTRACT NO. DE-AC09-96SR18500 


\section{DISCLAIMER}

This report was prepared as an account of work sponsored by an agency of the United States Government. Neither the United States Government nor any agency thereof, nor any of their employees, makes any warranty, express or implied, or assumes any legal liability or responsibility for the accuracy, completeness, or usefulness of any information, apparatus, product, or process disclosed, or represents that its use would not infringe privately owned rights. Reference herein to any specific commercial product, process, or service by trade name, trademark, manufacturer, or otherwise does not necessarily constitute or: imply its endorsement, recommendation, or favoring by the United States Government or any agency thereof. The views and opinions of authors expressed herein do not necessarily state or reflect those of the United States Government or any agency thereof.

This report has been reproduced directly from the best available copy.

Available to DOE and DOE contractors from the Office of Scientific and Technical Information, P.O. Box 62, Oak Ridge, TN 37831; prices available from (615) 576-8401.

Available to the public from the National Technical Information Service, U.S. Department of Commerce; 5285 Port Royal Road, Springfield, VA 22161. 


\section{DISCLAIMER}

Portions of this document may be illegible in electronic image products. Images are produced from the best available original document. 
WSRC-TR-99-00110, Revision 0

Distribution Category: Unlimited

Keywords: waste gless, phase separation, Glass durability, glass quality

Retention: Permanent

C. M. JANTZEN and R. L. SCHULZ

Westinghouse Savannah River Technology Center

Aiken, SC 29808

Prepared for:

Tank Waste Focus Area

TTP\# SR1-6-WT-31

Subtask A.2

Milestone A.2-4

Approved by:

E.W. Holtzscheiter, Research Manager

Defense Waste Processing Technology

Publication Date: April 1, 1999

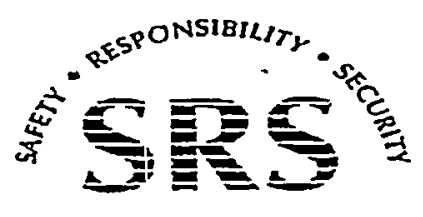

PREPARED FOR TIIE U.S. DEPARTMENT OF ENERGY UNDER CONTRACT NO. DE-AC09-96SR18500 


\section{Approvals}

Caul in tantzen

C.M. Jantzen, Authot

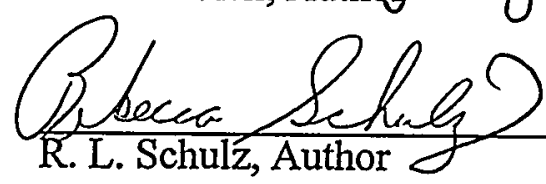

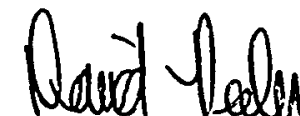

D. K. Peeler, Technical Reviewer

Canzed A CMand

D.A. Crowley, Level 4 Manager,

Immobilization Waste Technology

Ewblaltrahulo

E. W. Holtzscheiter, Level 3 Manager,

Immobilization Waste Technology

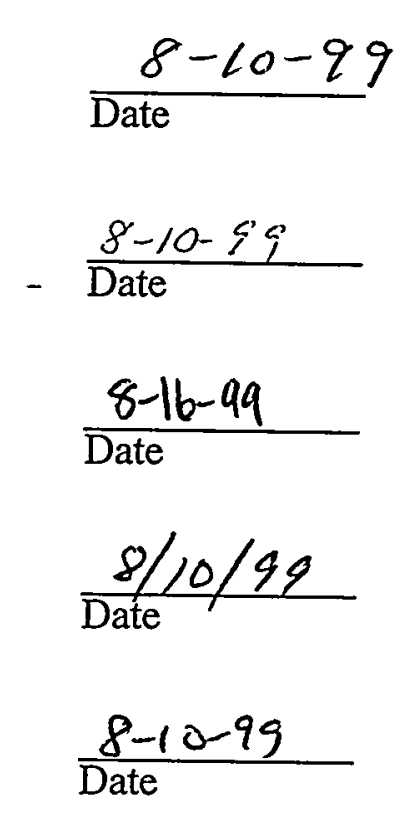




\title{
TEST PLAN FOR EFFECT OF PHASE SEPARATION ON OPTIMIZATION OF WASTE LOADING IN HIGH LEVEL WASTE GLASSES (U)
}

\author{
C. M. JANTZEN and R. L. SCHULZ \\ Westinghouse Savannah River Company \\ Savannah River Site \\ Aiken, South Carolina 29808
}

\subsection{INTRODUCTION}

Several types of phase transformations can occur in glass. The most commonly occurring phase transformations are crystallization and/or liquid-liquid phase separation (Figure 1). Crystallization is the growth of a crystalline phase(s) which may or may not have the same composition as the original liquid. ${ }^{1}$ There are two principle types of crystallization:

- $\quad$ Surface crystallization where crystal growth begins (i.e. nucleates) from the melt-atmosphere interface or the melt-container interface and grows perpendicular to this interface ${ }^{1}$

- Volume crystallization where crystal growth begins from nucleation sites within a melt; volume crystallization can be either heterogeneous or homogeneous

- heterogeneous nucleation occurs if the initiating site for crystallization is a substance foreign to the bulk of the melt ${ }^{1}$, e.g. a steel or refractory impurity, a bubble, a melt insoluble, etc.

- homogeneous nucleation occurs if the initiating site for crystallization is a nucleus of the melt itself ${ }^{1}$

Liquid-liquid phase separation is the growth of non-crystalline glassy phases which will have a different composition from the overall melt. ${ }^{1}$ Phase separation in glasses generally takes the form of two immiscible glass phases which differ in chemical compasition and surface tension. Separation into two phases may have various causes but the final result is that the original structurally homogeneous glass is separated into two or more vitreous (noncrystalline) phases of different density. If the liquid-liquid immiscibility is "quenched in" when the glass is cooled to room temperature it is often termed glass-in-glass phase separation. There are two principle types of liquid-liquid or glass-in-glass phase separation:

- Spinodal decomposition which is a glass compositional region where small fluctuations (normally in the range of $20-100 \mathrm{~A}$ ) in melt composition can cause the melt to separate into two phases spontaneously, e.g. there is no free energy barrier to overcome in order for the melt to separate A. Paul, "Chemistry of Glasses," Chapman \& Hall, London, 293pp., (1982). 
- Homogeneous nucleation as defined above where there is a free energy barrier to the melt separation which nust be overcome by the formation of a critical size compositional fluctuation in the melt

Thus phase separation and crystallization are not the same phenomena but are related, e.g. phase separation can induce crystallization to occur (Figure1), e.g. in borosilicate glasses containing phosphate phase separation of phosphate rich droplets in the borosilicate matrix precedes crystallization of the phosphate droplets into alkali or alkaline phosphate phases. ${ }^{2}$

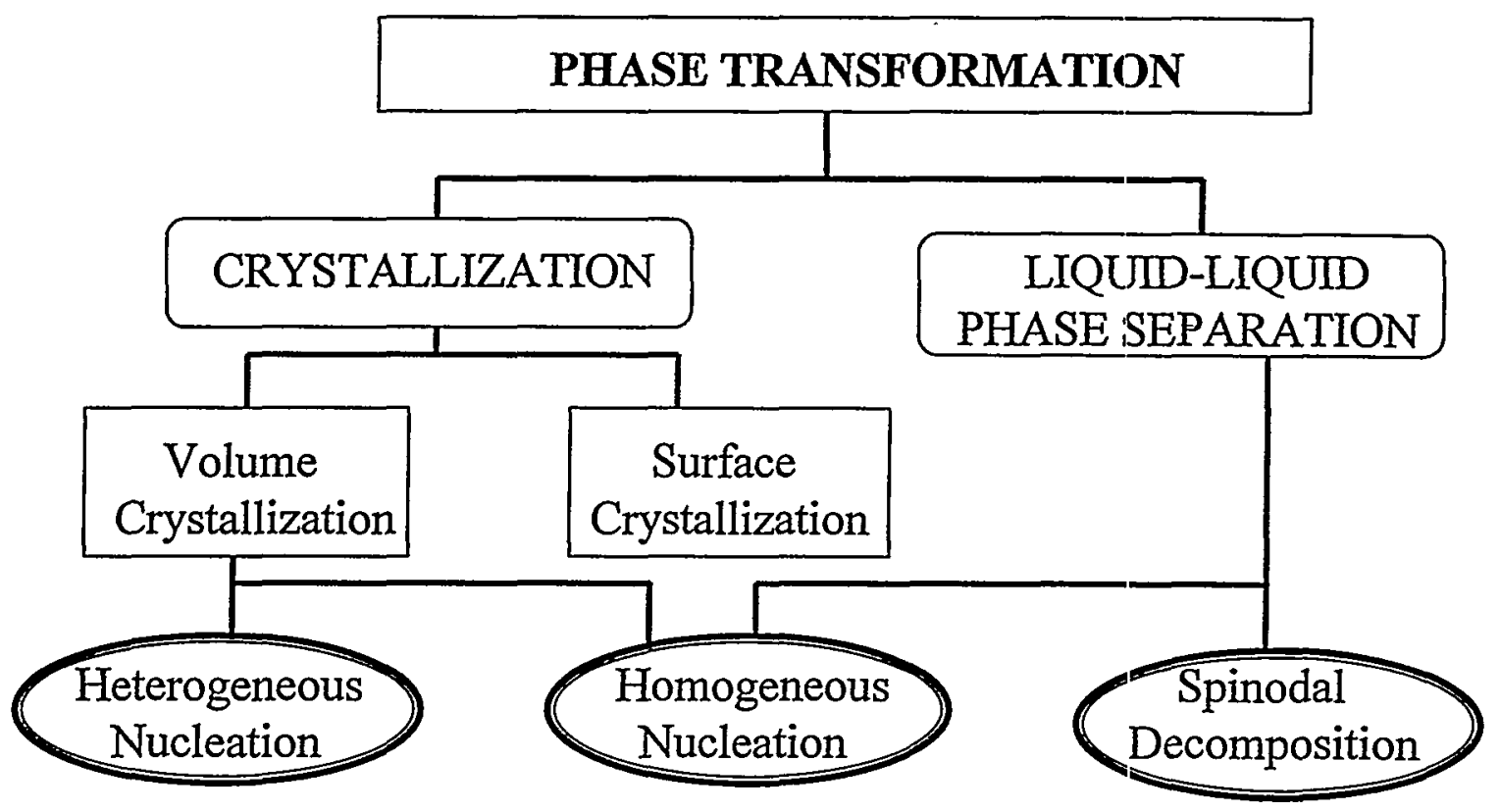

Figure 1. Schematic of the types of phase transformations that can occur in glass (from Paul ${ }^{1}$ )

Controlling the glass chemistry in compositional regions that avoid phase separation is key to controlling glass durability and processing. Depending upon such factors as the relative density of the two liquids, their viscosities, their interphase surface energy, and the melt conditions, the two liquids may separate on the following scales:

- gross macroscopic scale resulting in two separate liquid layers in a melter ${ }^{3}$ or crucible

- each of the two separate phases may be homogeneous

- one or both of the two separate phases may be phase separated on a microscopic scale

- microscopic scale resulting in what visually looks like a homogeneous glass.

2 W. Vogel, "Chemistry of Glass," American Ceramic Society, Columbus, OH, 325pp. (1985)

3 L.A. Chick, G.L. McVay, G.B. Mellinger, and F.P. Roberts, "Annual Report on the Development and Characterization of Solidified Forms for Nuclear Wastes," 1979, U.S. DOE Report PNL-3465, Battelle Pacific Northwest Laboratory (December, 1980). 
Macroscopic phase separation has been found to be detrimental to the stability and durability of nuclear waste glasses. ${ }^{4}$ In addition, macroscopic phase separation can cause processing difficulties if phases of different density and viscosity are stratified within a melter.

Phase separation, if it occurs on a microscopic scale, has been shown to be detrimental to the stability and durability of nuclear waste glasses, ${ }^{5.6 .7}$ implying that one of the immiscible phases is more soluble than the other. Phase separation complicates modeling of glass durability as a function of composition because the composition of the overall glass is known but the compositions of the two individual phases composing the glass is not known. For the waste glasses studied, the durability is dominated by the more soluble phase causing the overall poorer durability of phase separated glasses (Figure 2).

The amount of phase separation in a given glass is a strong function of the thermal history and/or heat treatment ${ }^{8}$ to which a glass is subjected. The extent of phase separation can, therefore, only be controlled during production of glass if the thermal history and/or heat treatment is controlled. Phase separation is, therefore, considered undesirable if the cooling rate (thermal history) of the glass process is not controlled. If a given glass composition has a tendency to phase separate, then the thermal history of the waste glass during solidification in a waste canister, and the effects of heat from radioactive decay in a repository waste package can all impact the kinetics of phase separation and thus, the long term durability of a waste glass. For uncontrolled cooling rate processes it is desirable to avoid glass compositions that can potentially phase separate.

Morphologically, glass-in-glass phase separation may take the form of clroplets or channels of various dimensions which have defined boundaries. Visual observation of glass-in-glass phase separation with the naked eye and/or an optical microscope is sometimes possible but the scale of the phase separation must be relatively large and/or macroscopic. Microscopic phase separation can be seen in a scanning electron microscope (SEM) if the size of the glass-in-glass phase separation is sufficiently large and/or the densities of the two glasses are sufficiently different that the phase boundaries are well defined.t If the phase separation is not sufficiently large and/or the densities of the two phases are not sufficiently different, then phase separation may only be visible with a transmission electron microscope (TEM).

4 A.D. Cozzi and C.M. Jantzen, "Glass Durability Along the Compositional Continuum Between a Phase Separated Frit and a Homogeneous Glass, Proceedings of 1999 American Ceramic Society Annual Meeting.

5 C.M. Jantzen, J.B. Pickett, K.G. Brown, T.B. Edwards, U.S. Patent \# 846,278, “Method of Determining Glass Durability"' (THERMO'TM)' (December 8, 1998).

6 P.R. Hrma, D.K. Peeler, et. al, "Property/Composition Relationships for Hanford High-Level Waste Glass Melting at $1150^{\circ} \mathrm{C}$,' US DOE Report PNL-10359, Vols 1 and 2 (December, 1994).

7 I. Tovena, T. Advocat, D. Ghaleb, E. Vernaz and F. Larche, "Thermodynamic and Structural Models Compared with the Initial Dissolution Rates of 'SON' Glass Samples," Scientific Basis for Nuclear Waste Management, XVII, A. Barkatt and R.A. Van Konynenburg (Eds.), Materials Research Society, Pittsburgh, PA, 595-602 (1994).

8 M.B. Volf, "Chemical Approach to Glass," Glass Science and Technology, V. 7, Elsevier Science Publishing Co., Inc, New York, 594 pp (1984).

$\dagger \quad$ Often samples can be etched with acid and/or steam to accentuate the morphology of the least soluble phase and facilitate observation in an electron microscope. 


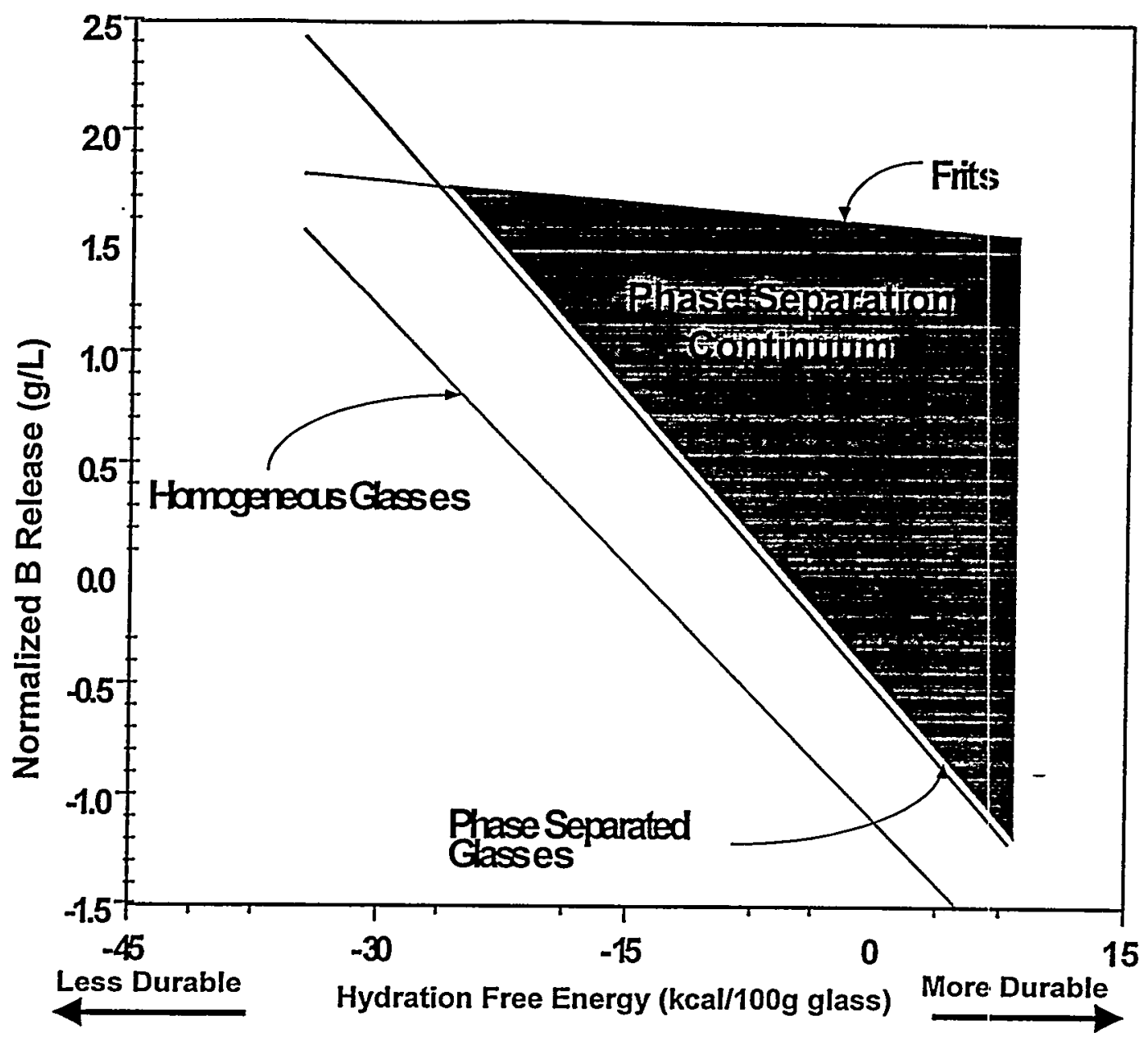

Figure 2. Modeling of glass durability response as given by the log boron release from the ASTM C12-85 (PCT) test versus composition as given by the Thermodynamic Hydration Reaction Model (THERMO).5

If phase separation is occurring by spinodal decomposition, the early stages of the decomposition only exhibit diffuse boundaries which are characterized by composition modulations which can be as small as 20-100A. ${ }^{9}$ The scale of this type of phase separation requires observation in a TEM and is often so small that even a TEM. is inadequate or inconclusive because observed phase connectivity and periodicity is not considered to be unequivocal evidence of spinodal decomposition ${ }^{10.11} \cdot 12$ since anisotropic strain fields can give rise to periodicity ${ }^{11}$ and discontinuous cellular structures can give rise to lamellar structures. ${ }^{12}$ Therefore, conventional electron microscopy often cannot substantiate phase separation by a spinodal mode without additional kinetic studies of the evolution of the new phases with time via small angle neutron scattering (SAXS or SANS) techniques. ${ }^{13 \cdot 14 \cdot 15 \cdot 16}$

9 J.W. Cahn and R.J. Charles, "Initial Stages of Phase Separation in Glasses" Phys. Chem. Glasses, 6[5], 181-191 (1965).

10 T.P. Seward III, D.R. Uhlmann, and D. Turnbull, "Development of a Tw'o-Phase Structure in Glasses with Special Reference to the System BaO-SiO 2 " J. Am. Cerain. Soc., 51[11], 634-643 (1968).

11 A.J. Ardell, R.B. Nicholson, and J.D. Eshelby, "Modulated Structure of Aged Nickel-Aluminum Alloys," Acta Met., 14[3], 1295-1309 (1966).

12 H. Herman and R.K. MacCrone, "Comments on Separation of Phases by Spinodal Decomposition in the Systems $\mathrm{Al}_{2} \mathrm{O}_{3}-\mathrm{Cr}_{2} \mathrm{O}_{3}$ and $\mathrm{Al}_{2} \mathrm{O}_{3}-\mathrm{Cr}_{2} \mathrm{O}_{3}-\mathrm{Fe}_{2} \mathrm{O}_{3}$," J. Am. Ceram. Soc. 55[1], 50 (1971). C.M. Jantzen and H. Herman, "Spinodal Decomposition: Phase Diagram Representation and 


\subsection{BACKGROUND}

The compositional dependence of commercial glasses formed in the $\mathrm{M} 2 \mathrm{O}-\mathrm{SiO}_{2}-\mathrm{Al}_{2} \mathrm{O}_{3}-\mathrm{B}_{2} \mathrm{O}_{3}$ glass forming systems, where $\mathrm{M}=\mathrm{K}, \mathrm{Na}$, or $\mathrm{Li}$, are well understood. ${ }^{8}$. Alkali borosilicate glasses in the compositional systems $\mathrm{M}_{2} \mathrm{O}-\mathrm{SiO}_{2}-\mathrm{B}_{2} \mathrm{O}_{3}$ are known to have large phase separated regions in ternary composition space (Figures 3 and 4) where an alkali-borate or alkaline earth-borate rich glass can separate from an alkali-aluminosilicate rich glass. The width of the phase separated region in these ternary oxide systems is a function of the size of the alkali ion, e.g., lithium being the smallest alkali ion has the largest region of phase separation of all the alkali ions.
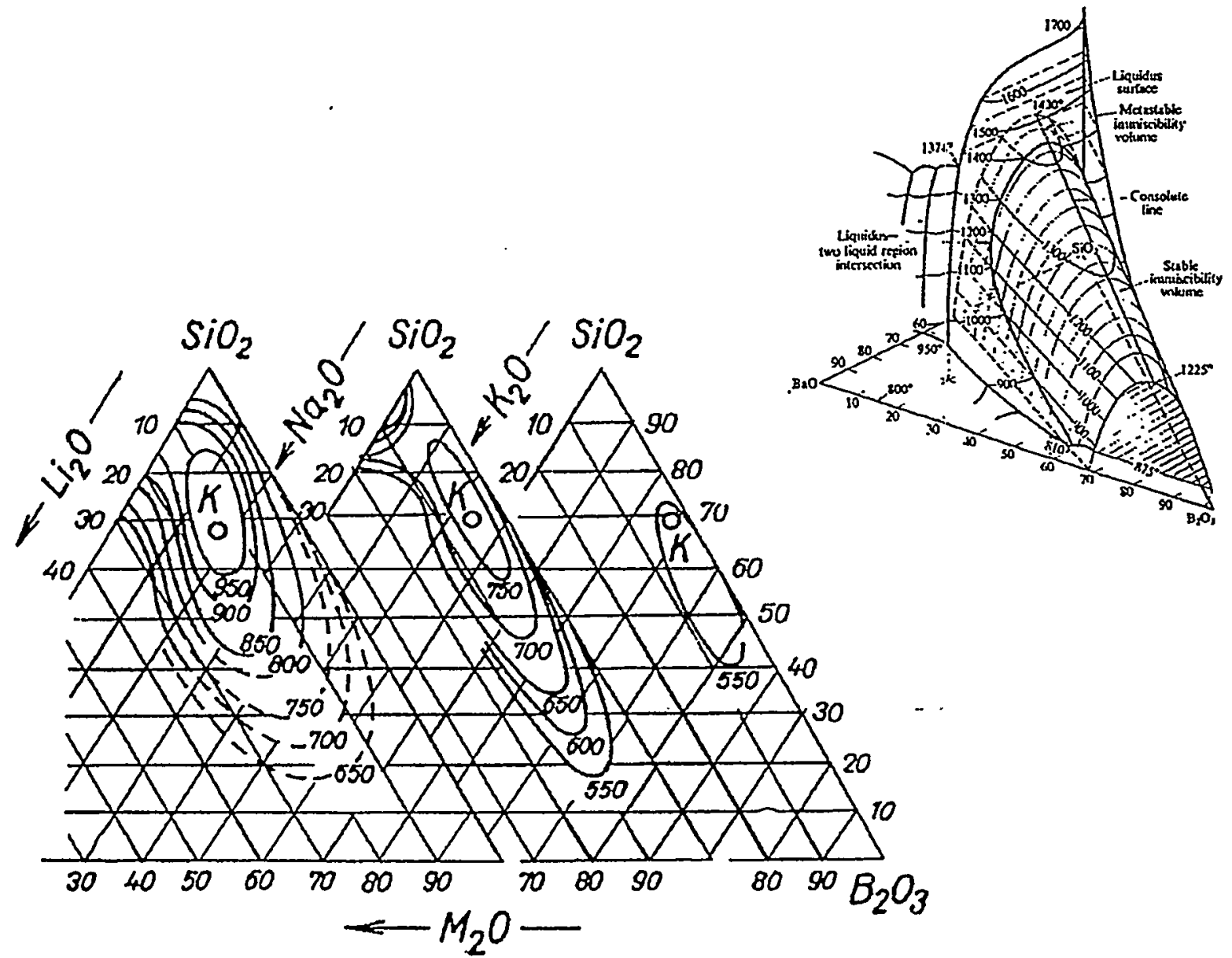

Figure 3. Comparison of the separation regions in $\mathrm{M}_{2} \mathrm{O}-\mathrm{B}_{2} \mathrm{O}_{3}-\mathrm{SiO}_{2}$ systems (mole\%) where $\mathrm{K}$ represents the consolute temperature, e.g., the maximum temperature of the top of the immiscibility dome (the inset shows the shape of the immiscibility volume as a function of composition and temperature ${ }^{8}$ ).

Occurence, "Materials Science and Technology: High Temperature Materials, V. 5, A. Alper, (ed), Academic Press, New York, 127-148 (1978).

14 C.M. Jantzen, D. Schwahn, J. Schelten, and H. Herman, "The $\mathrm{SiO}_{2}-\mathrm{Al}_{2} \mathrm{O}_{3}$ System, I. Later Stage of Spinodal Decomposition and Metastable Immiscibility," Physics and Chemistry of Glasses, 22[5], 122-137 (1981).

I5 C.M. Jantzen, D. Schwahn, J. Schelten, and H. Herman, "The $\mathrm{SiO}_{2}-\mathrm{Al}_{2} \mathrm{O}_{3}$ System, II. The Glass Structure and Decomposition Model," Physics and Chemistry of Glasses, 22 [5], 138-144 (1981). C.M. Jantzen, and H. Herman, "Phase Equilibria in the $\mathrm{SiO}_{2}-\mathrm{Al}_{2} \mathrm{O}_{3}$ Systern," J. Am. Ceram. Soc., 62[3-4], 212-214 (1979). 
Phase separation of the glass-in-glass type has been observed in multicomponent nuclear waste glasses in the $\left(\mathrm{M}_{2} \mathrm{O}\right)-\left(\mathrm{SiO}_{2}+\mathrm{Al}_{2} \mathrm{O}_{3}\right)-\mathrm{B}_{2} \mathrm{O}_{3}$ system, e.g. ( $\mathrm{PNL}$ 77-107) containing >12 wt $\% \mathrm{~B}_{2} \mathrm{O}_{3}{ }^{17}$ and PNNL 76-683 containing $9.5 \mathrm{wt} \% \mathrm{~B}_{2} \mathrm{O}_{3}$, Hanford waste glass formulations with $13.3 \mathrm{wt} \% \mathrm{~B}_{2} \mathrm{O}_{3}$ ), ${ }^{18}$ and Savannah River Site glasses made with $\mathrm{Purex}$ (high $\mathrm{Fe}_{2} \mathrm{O}_{3}$ ) sludge and excess quantities of frit. ${ }^{19}$ Since waste glasses contain 15-20 components, phase separation in these complex systems is not well understood. However, many of the nuclear waste glass components are present in minor amounts and $>95 \%$ of the glass chemistry is dominated by the five major components, $\mathrm{M}_{2} \mathrm{O}-\mathrm{SiO}_{2}-\mathrm{Al}_{2} \mathrm{O}_{3}-\mathrm{B}_{2} \mathrm{O}_{3}-\mathrm{Fe}_{2} \mathrm{O}_{3}$, where $\mathrm{M}=\mathrm{K}+\mathrm{Na}$ $+\mathrm{Li}$. Although the compositional dependency of phase separation in the $\mathrm{M}_{2} \mathrm{O}-\mathrm{SiO}_{2}-\mathrm{Al}_{2} \mathrm{O}_{3}$ $\mathrm{B}_{2} \mathrm{O}_{3}-\mathrm{Fe}_{2} \mathrm{O}_{3}$ system has not been systematically studied, phase separation has been studied in the individual $\mathrm{M}_{2} \mathrm{O}-\mathrm{SiO}_{2}-\mathrm{B}_{2} \mathrm{O}_{3}$ systems (Figures 2), ${ }^{80}$ and in the $\left(\mathrm{M}_{2} \mathrm{O}+\mathrm{MO}\right)$ $\left(\mathrm{SiO}_{2}+\mathrm{Al}_{2} \mathrm{O}_{3}\right)-\mathrm{B}_{2} \mathrm{O}_{3}$ systems, ${ }^{8}$ where $\mathrm{M}_{2} \mathrm{O}$ is any alkali oxide and $\mathrm{MO}$ is any alkaline earth oxide.

A composite ternary diagram has been constructed for use in defining generalized regions of phase separation in the $\mathrm{M}_{2} \mathrm{O}-\mathrm{SiO}_{2}-\mathrm{Al}_{2} \mathrm{O}_{3}-\mathrm{B}_{2} \mathrm{O}_{3}$ system (Figure 4). The largest

experimentally determined region for phase separation in a $\mathrm{M}_{2} \mathrm{O}-\mathrm{SiO}_{2}-\mathrm{B}_{2} \mathrm{O}_{3}$ type system, the $\mathrm{Li}_{2} \mathrm{O}-\mathrm{SiO}_{2}-\mathrm{B}_{2} \mathrm{O}_{3}$ system, ${ }^{19}$ and the $\mathrm{SiO}_{2}$ apex region of phase separation ${ }^{8}$ above the boldly dashed line $\mathrm{V}-\mathrm{W}$ in Figure 3 are superimposed on this generalized phase diagram of the $\mathrm{M}_{2} \mathrm{O}-\mathrm{SiO}_{2}-\mathrm{Al}_{2} \mathrm{O}_{3}-\mathrm{B}_{2} \mathrm{O}_{3}$ system where $\mathrm{M}=\mathrm{K}+\mathrm{Na}+\mathrm{Li}$. Above the line $\mathrm{V}-\mathrm{W}$ in Figure 4, the phase separation morphology is of the $\mathrm{SiO}_{2}$ rich droplet form. ${ }^{8}$ This composite diagram defines worst case boundaries in the $\mathrm{M}_{2} \mathrm{O}-\mathrm{SiO}_{2}-\mathrm{Al}_{2} \mathrm{O}_{3}-\mathrm{B}_{2} \mathrm{O}_{3}$ system, e.g., if $\mathrm{Li}_{2} \mathrm{O}$ were the only alkali ion in a glass in the absence of $\mathrm{Al}_{2} \mathrm{O}_{3}$ and/or if a waste glass contains so much $\mathrm{SiO}_{2}$ or $\mathrm{SiO}_{2}+\mathrm{Al}_{2} \mathrm{O}_{3}$ that the composition falls into the region above line $\mathrm{V}-\mathrm{W}$ in the $\mathrm{M}_{2} \mathrm{O}$ $\mathrm{SiO}_{2}-\mathrm{B}_{2} \mathrm{O}_{3}$ system. Therefore, waste glass compositions which lie in the striped region in Figure 4, including the glasses in the region above line V-W have been found to phase separate versus glasses within the white circular region where homogeneous waste glasses are known to form. ${ }^{21}$

Although the ternary $\mathrm{\Sigma M}_{2} \mathrm{O}-\mathrm{Al}_{2} \mathrm{O}_{3}-\mathrm{SiO}_{2}-\mathrm{B}_{2} \mathrm{O}_{3}$ system (Figure 4) describes some of the compositional relations between homogeneous and phase separated glasses, it does not include the compositional effects of $\mathrm{Fe}_{2} \mathrm{O}_{3}$ which is a main component of many waste glasses. If the effects of $\mathrm{Fe}_{2} \mathrm{O}_{3}$ are considered, e.g. the $\mathrm{Na}_{2} \mathrm{O}-\mathrm{Li}_{2} \mathrm{O}-\mathrm{K}_{2} \mathrm{O}-\mathrm{Al}_{2} \mathrm{O}_{3}-\mathrm{B}_{2} \mathrm{O}_{3}-\mathrm{Fe}_{2} \mathrm{O}_{3}$ $\mathrm{SiO}_{2}$ system, then these seven major oxides dominate $\sim 90 \%$ of the glass chemistry.

17 M. Tomozawa, G.M. Singer, Y. Oka, and J.T. Warden, "Phase Separation in Nuclear Waste Glasses," Ceramics in Nuclear Waste Management, T.D. Chikalla and J.E. Mendel (Eds.), U.S. Dept. of Energy, Technical Information Center, Springfield, VA, CONF-790420, 193-196 (1979). N.D. Hutson, "Integrated DWPF Melter System (IDMS) Campaign Report: Hanford Waste Vitrification Plant (HWVP) Process Demonstration," U.S. DOE Report WSRC-TR-92-0403, Rev. 1 (June 11, 1993).

19 C.M. Jantzen, J.B. Pickett, K.G. Brown and T.B. Edwards, "Impact of Phase Separation on Waste Glass Durability, Proceedings of 1999 American Ceramic Society Annual Meeting.

20 B.S.R. Sastry and F.A. Hummel, "Studies in Lithium Oxide Systems: III. Liquid Immiscibility in the System $\mathrm{Li}_{2} \mathrm{O}-\mathrm{B}_{2} \mathrm{O}_{3}-\mathrm{SiO}_{2}$," J. Am. Ceram. Soc., 42, $81-88$ (1959).

21 C.M. Jantzen, "Systems Approach to Nuclear Waste Glass Development," J. Non-Crystalline Solids, 84, 215-225 (1986). 


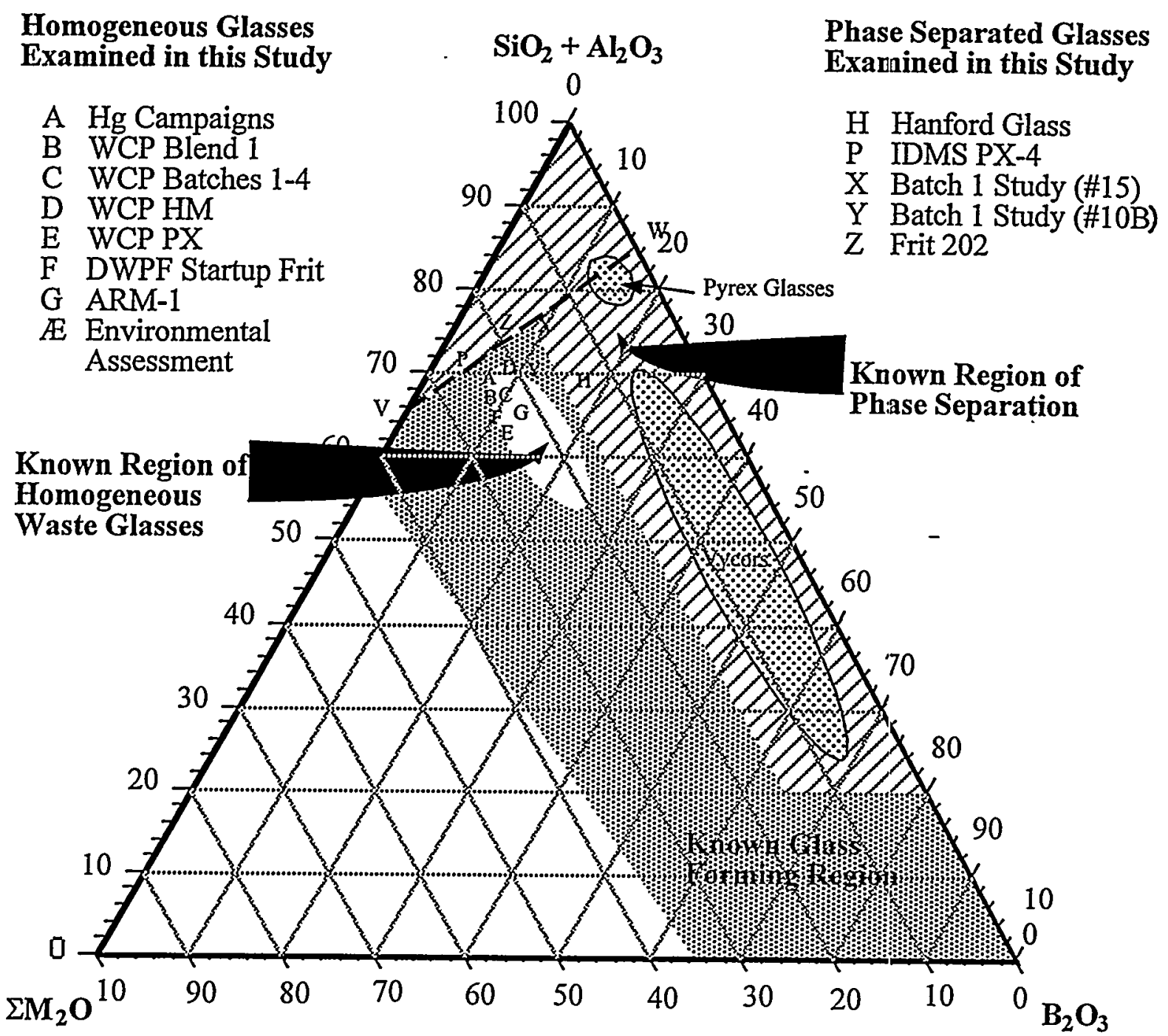

Figure 4. Compositions of homogeneous and phase separated glasses overlain on the generalized $\Sigma \mathrm{M}_{2} \mathrm{O}-\mathrm{SiO}_{2}-\mathrm{Al}_{2} \mathrm{O}_{3}-\mathrm{B}_{2} \mathrm{O}_{3}$ ternary phase diagram (in $\mathrm{wt} \%$ ). The Hanford glass listed is the one melted in the Process Demonstration given in Reference 18.

A more detailed study of the effects of waste glass composition on phase separation was performed in $1995.5,18$ This study was based on a population of 110 glasses compositionally within the DWPF processing range. Of the 110 glasses examined, 22 were determined to be phase separated by either scanning electron microscopy (SEM) or transmission electron microscopy (TEM). These glasses were from both laboratory scale crucible melts and from production in the 1/10th scale DWPF melter (the Integrated DWPF Melter System, IDMS). The compositional dependence of the phase separated versus homogeneous glasses was studied and a compositionally dependent process model was developed fiom the data in Figure 5. 


\section{WRSC-TR-99-00110, Revision 0}

Glasses have a high probability of being homogeneous if the following criterion is satisfied:

$$
-1.6035 x-5.6478 y+210.9203<0
$$

where $\mathrm{y}=$ Dense Sludge Components $=\mathrm{Al}_{2} \mathrm{O}_{3}+\left(\mathrm{Fe}_{2} \mathrm{O}_{3}+\mathrm{FeO}\right.$ calculated as $\left.\mathrm{Fe}_{2} \mathrm{O}_{3}\right)+\mathrm{Nd}_{2} \mathrm{O}_{3}$ $+\mathrm{Ce}_{2} \mathrm{O}_{3}+\mathrm{La}_{2} \mathrm{O}_{3}+\mathrm{Y}_{2} \mathrm{O}_{3}+\mathrm{CaO}+\mathrm{MoO}_{3}(\mathrm{wt} \%)$

$$
\mathrm{x}=\text { Less Dense (Frit) } \dagger \text { Components }=\underset{(\mathrm{wt} \%)}{\mathrm{Na}} \mathrm{O}+\mathrm{Li}_{2} \mathrm{O}+\mathrm{K}_{2} \mathrm{O}+\mathrm{Cs}_{2} \mathrm{O}+\mathrm{SiO}_{2}+\mathrm{B}_{2} \mathrm{O}_{3}
$$

The glasses that were predicted to be phase separated leached at elevated concentrations of B and other constituents when tested using the Product Consistency Test (ASTM C1285-94). It should be noted that weight percent is used preferentially over normalized mole percents or mole fraction in Equation 1 because glass-in-glass phase separation, including spinodal decomposition, is the separation of two immiscible phases that have different compositions and different densities. ${ }^{22,14,15}$ Indeed, the dependence of the reciprocal of the density of each phase on the glass composition in weight percent is linear. ${ }^{22}$

In order to validate Equation 1 a database was developed from the known literature of glass phase separation. The validation database included 53 glasses for which glass compositions were available in addition to glass homogeneity information derived from one of the following techniques: (1) SEM, (2) TEM, or (3) Small Angle Neutron Scattering (SANS). The validation database included DWPF type waste glasses, DWPF frits, Pyrex, NBS SRM 623 , PNL waste glasses, and a United Kingdom Harwell waste glass. Of the 53 validation glasses modeled $95 \%$ were correctly classified by Equation 1.

It should be noted that Equation 1 was generated from a mixture of rapidly quenched (pan quenched) glasses, crucible or air quenched glasses, and production glasses poured from the IDMS melter. In order to evaluate the impact of quench rate on the classification of a glass as homogeneous or phase separated, the role of quench rate must be evaluated.

$\dagger \quad$ The frit components term includes the sum of all sources of alkali species (frit, sludge, PHA, and $\mathrm{Na}$ from $\mathrm{NaNO}_{2}$ ) plus $\mathrm{B}_{2} \mathrm{O}_{3}$ and $\mathrm{SiO}_{2}$.

22 O.V. Mazurin and E.A. Porai-Koshits, "Phase Separation in Glass," North Holland Publishing Co., Amsterdam, 369p. (1984). 


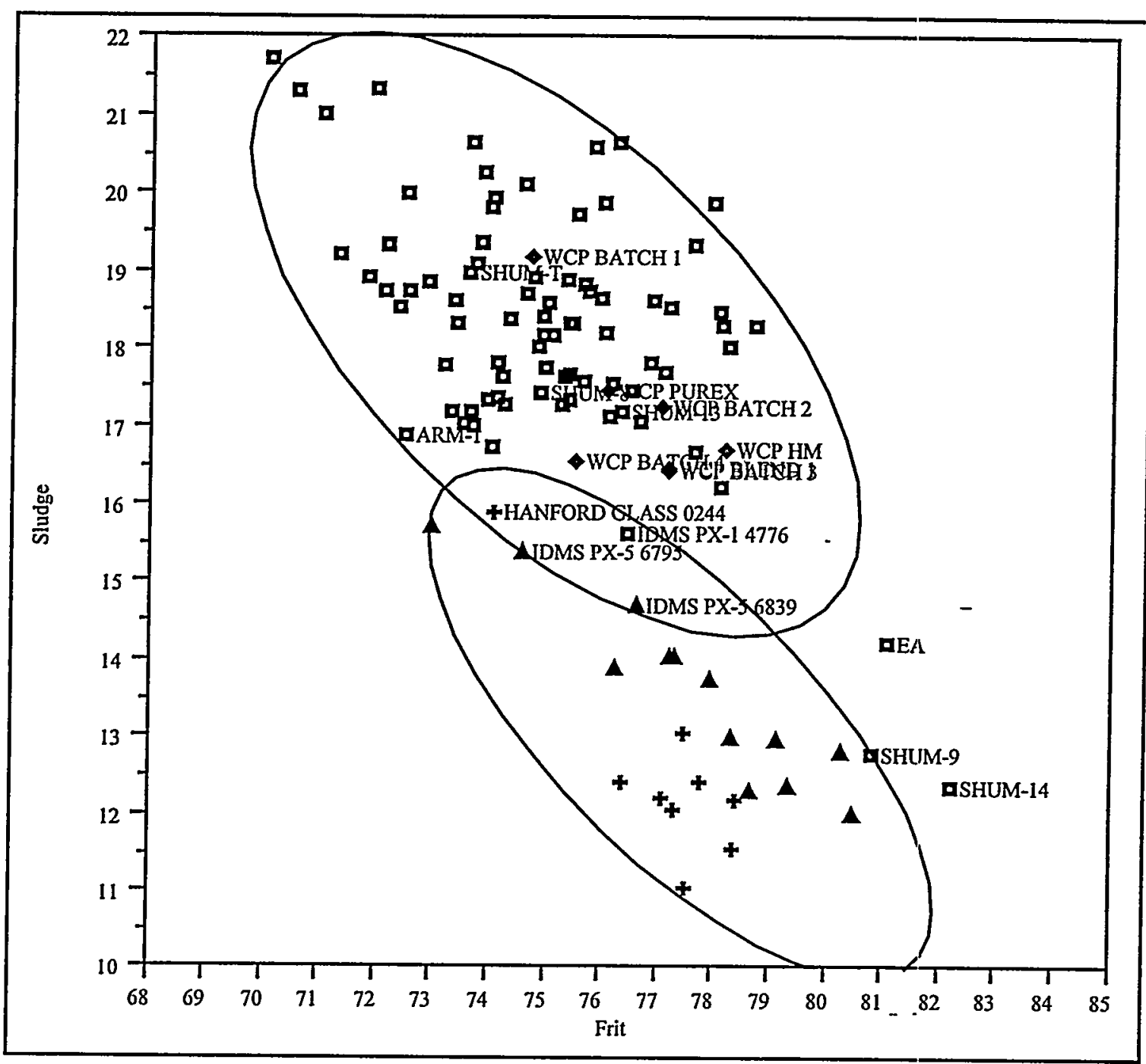

Figure 6. Graphical representation of 14 component composition space in 2-dimensions. Homogeneous glasses are indicated by the squares, phase separated glasses are indicated by triangles and crosses. 


\subsection{Task Definition and Task Responsibilities}

\subsection{Compositional Nature of Glass-in-Glass Phase Separation (Table I)}

Phase separation, of the glass-in-glass type is favored in compositions which do not allow the network breaking and modifying cations to be properly surrounded by non-bridging oxygen ions, e.g., compositions too high in alkali and/or too low in silica. 23,24 Likewise, mixed alkali effects can cause phase separation in glasses, ${ }^{25}$ e.g., where dissimilar sized monovalent ions exist in the same glass, the largest and smallest diameter cations will separate into different glass phases. In addition, some minor components such as $\mathrm{U}, \mathrm{Ti}$, or: $\mathrm{P}$ may play a role in phase separation. Development of a phosphate term for the phase separation model will be examined in this study as applicable to vitrification of Idaho National Energy and Engineering Laboratory's (INEEL) sodium bearing waste (SBW) and INEEL's high $\mathrm{Al}_{2} \mathrm{O}_{3}$.

\section{Table I}

\section{Tasks to Determine the Compositional Nature of Glass-in-Glass Phase Separation}

\begin{tabular}{|c|c|c|c|}
\hline TASK & METHOD & TECHNQUE & PERSON(S) \\
\hline $\begin{array}{l}\text { Phosphate } \\
\text { Effects }\end{array}$ & $\begin{array}{l}50 \text { crucible melts and }-60 \text { melts from } \\
\text { both a pilot scale and a full scale } 5 \text { ton a } \\
\text { day melter run containing } 1-5 \text { wt\% } \mathrm{U}_{3} \mathrm{O}_{8} \text {, } \\
\text { low } \mathrm{Fe}_{2} \mathrm{O}_{3} \text {, and high } \mathrm{Al}_{2} \mathrm{O}_{3} \text {, and high } \\
\text { alkali, and phosphate }\left(\mathrm{as} \mathrm{PO}_{4} \text { ) ranging }\right. \\
\text { from } 0.19-4.0 \text { wt\% were formulated in } \\
\text { the alkali-borosilicate system in known } \\
\text { regions of phase separation and } \\
\text { homogeneity. ASTM C-1285 (PCT) } \\
\text { analyses and analyzed glass compositions } \\
\text { are already available. }\end{array}$ & $\begin{array}{l}\text { Examine glasses for } \mathrm{PO}_{4} \text { phase } \\
\text { separation. } \\
\text { Use glass chemistries and } \mathrm{PCT} \\
\text { response to add a } \mathrm{PO}_{4} \text { term to } \\
\text { Equation } 1 \text { if possible or define a } \\
\text { solubility limit based on alkali, } \\
\text { alkaline earth phosphate } \\
\text { formation. }\end{array}$ & $\begin{array}{l}\text { C.M. Jantzen } \\
\text { R.L. Schulz } \\
\\
\text { C.M. Jantzen } \\
\text { K.G. Brown }\end{array}$ \\
\hline $\begin{array}{l}\text { Phosphate } \\
\text { Effects }\end{array}$ & $\begin{array}{l}\text { ASTM C-1285 and glass chemistry data } \\
\text { is being generated for } P \text { containing } \\
\text { glasses under subtask } A 1^{26}\end{array}$ & $\begin{array}{l}\text { Examine high P containing } \\
\text { glasses in XRD/SEM/TEM for } \\
\text { relation of P phase separation to } \\
\text { crystallization in this system. } \\
\text { Depending on results acquired } \\
\text { use glass chemistries to add a } P \\
\text { term to Equation } 1 \text { if possible or } \\
\text { define a solubility limit based on } \\
\text { alkali, alkaline earth phosphate } \\
\text { formation. }\end{array}$ & $\begin{array}{l}\text { C.M. Jantzen } \\
\text { R.L. Schulz } \\
\\
\text { C.M. Jantzen } \\
\text { K.G. Brown }\end{array}$ \\
\hline $\begin{array}{l}\text { Extend } \\
\text { phase } \\
\text { separation } \\
\text { databases }\end{array}$ & $\begin{array}{l}\text { Compile data from } 1995 \text {-current } \\
\text { including data from A. D. Cozzi } \\
\text { generated under funding from TFA }\end{array}$ & Computational Modeling & $\begin{array}{l}\text { G. Ritzhaupt } \\
\text { (summer } \\
\text { ORISE) }\end{array}$ \\
\hline
\end{tabular}
B.E. Warren and A.G. Pincus, "Atomic Consideration of Immiscibility in Glass Systems," J. Am. Ceram. Soc., 23, 301-304 (1940).

24 V. McGahay and M. Tomozawa, "The Origin of Phase Separation in Silicate Melts and Glasses," J. Non-Cryst. Solids, 109[1], 27-34 (1989).

25 Y. Kawamoto and M. Tomozawa, "The Mixed Alkali Effect in the Phase Separation of Alkali Silicate Glasses," Phys. Chem. Glasses, 23[2], 72-75 (1982).

26 B.A. Staples, D.K. Peeler, J.D. Vienna, B.A. Scholes and C.A. Musick, "The Preparation and Characterization of INTEC HAW Phase 1 Compositionn Variation Study Glasses," INEEL/EXT-98-00970, Rev. 1 (March, 1999). 


\subsection{Effects of Phase Separation on Glass Durability}

Table II

Tasks to Determine the Effects of Glass-in-Glass Phase Separation on Glass Durability

\begin{tabular}{|c|c|c|c|}
\hline TASK & METHOD & TECHNIQUE & PERSON(S) \\
\hline $\begin{array}{l}\text { Phosphate } \\
\text { Effects }\end{array}$ & $\begin{array}{l}\text { ASTMC-1285 and glass chemistry data is } \\
\text { being generated for P containing glasses } \\
\text { under subtask } A \text { and PCT data is available } \\
\text { from } \sim 100 \text { glasses containing between } \\
0.19-4.0 \mathrm{wt} \% \mathrm{PO}_{4} \text { as given in Subtask 3.1. }\end{array}$ & $\begin{array}{l}\text { Use PCT analyses to validate } \\
\text { the effects of } P \text { on glass } \\
\text { durability for phase separated } \\
\text { and homogeneous glasses. }\end{array}$ & $\begin{array}{l}\text { C.M. Jantzen } \\
\text { K.G. Brown } \\
\text { D.K. Peeler }\end{array}$ \\
\hline $\begin{array}{l}\text { Composition } \\
\text { Of Phases }\end{array}$ & $\begin{array}{l}\text { Attempt to determine the compositional } \\
\text { nature of the two separating phases }\end{array}$ & $\begin{array}{l}\text { SEM/TEM with EDAX, if } \\
\text { microscopic; wet chemistry if } \\
\text { macroscopic }\end{array}$ & R.L. Schulz \\
\hline $\begin{array}{l}\text { ExtendPCT } \\
\text { databases }\end{array}$ & $\begin{array}{l}\text { Examine PCT data derived on waste } \\
\text { glasses including phase separated glasses } \\
\text { from } 1995 \text {-current including data from } \\
\text { A.D. Cozzi generated under funding from } \\
\text { TFA }\end{array}$ & $\begin{array}{l}\text { Computational Modeling } \\
\text {. }\end{array}$ & $\begin{array}{l}\text { G. Ritzhaupt } \\
\text { (summer } \\
\text { ORISE) }\end{array}$ \\
\hline
\end{tabular}

\subsection{Effects of Kinetics on The Scale of Phase Separation and on Crystallization}

In 1995 Jantzen, et.al. ${ }^{5}$ demonstrated that cooling of a phase separated frit at different rates could enhance the extent of phase separation, e.g. at slower cooling rates a larger volume fraction of the glass phase separated. Indeed, even at the fastest quenching rate (that of pouring the molten glass into a steel pan), the phase separation could not be avoided. ASTM C-1285 (PCT) testing of the rapidly quenched vs. more slowly quenched (e.g. cooling in the crucible) indicated that there was a small but measurable impact on the durability of the glass. The issue of cooling kinetics in a waste canister is illustrated in Figure 6 . This figure depicts three cases of influence of cooling kinetics in terms of time-temperature-

transformation (TTT) curves for phase separated glass (note that regions of secondary crystallization are indicated for glasses in which crystallization is a secondary effect caused by phase separation). Crystallization can also occur in the absence of phase separation.

Phase separation when it occurs is usually a very rapidly forming phenomena, it occurs often during cooling and is only enhanced either in scale or in extent (volume fraction) by slower cooling. Figure 6 Case $\mathrm{A}$ indicates that if laboratory melts are rapidly quenched, e.g. at rates characteristic of the canister outer surface, and the glass phase separates, then the glass in the entire waste canister will be phase separated. If the glass does not phase separate when rapidly cooled (Figure 6,Case B), then either the glass is not prone to phase separation at all (see Case C) or some small interior portion of the glass in the center of the canister may be prone to phase separate. This is equivalent to the situation in a canister where $~ 5 \%$ crystallization was shown not to impact the glass quality of an entire glass canister. ${ }^{27}$ If the glass is cooled via the canister centerline cooling curve (Figure 6, Case $C$ ) then none of the glass in the canister will phase separate but this will define a smaller waste processing region.

In order to evaluate the impacts of cooling rate on phase separation and glass durability, different homogeneous glasses will be doped with phase separated frit until they phase 
separate. The phase separation will be monitored as a function of both inner and outer canister cooling. The scale and extent of phase separation will be determined to determine if phase separation is macroscopic or microscopic. ASTM C1285 (PCT) testing will be performed as necessary to determine the effect of phase separation on glass durability (see task definition in Section 3.2.

Table III

Tasks to Determine the Effects of Kinetics on The Scale of Glass-in-Glass Phase Separation

\begin{tabular}{|c|c|c|c|}
\hline TASK & METHOD & TECHNIQUE & PERSON(S) \\
\hline $\begin{array}{l}\text { Kinetics } \\
\text { and } \\
\text { Relation to } \\
\text { Crystallizati } \\
\text { on }\end{array}$ & $\begin{array}{l}\text { Examine the kinetics by which } \\
\text { phosphate rich glasses phase separate } \\
\text { and crystallize. }\end{array}$ & Literature study and SEM & C.M. Jantzen \\
\hline $\begin{array}{l}\text { Kinetics } \\
\text { and } \\
\text { Relation to } \\
\text { Crystallizati } \\
\text { on }\end{array}$ & $\begin{array}{l}\text { Choose } 3 \text { glasses which } \\
\text { compositionally are predicted to be } \\
\text { homogeneous by Equation } 1 \text {. Add } \\
\text { various quantities of a phase separated } \\
\text { frit until the waste glasses are forced to } \\
\text { phase separate. As many as } 10 \\
\text { combinations of a homogeneous glass } \\
\text { and a phase separated frit are to be } \\
\text { used. }\end{array}$ & $\begin{array}{l}\text { Prepare the } 3 \text { glass compositions by } \\
\text { rapidly quenching, by canister } \\
\text { centerline cooling, and by canister } \\
\text { outer surface cooling to ensure that } \\
\text { they phase separate. Study mode of } \\
\text { phase separation and scale as a } \\
\text { function of cooling, as a. function of } \\
\text { composition, and as a function of } \\
\text { density. } \\
\text { Perform ASTM C- } 1285 \text { testing on the } \\
\text { quenched and centerline cooled } \\
\text { glasses and compare the results. }\end{array}$ & R.L. Schulz \\
\hline $\begin{array}{l}\text { Relation of } \\
\text { scale to } \\
\text { durability }\end{array}$ & $\begin{array}{l}\text { The effects of the scale of the phase } \\
\text { separation will be examined by } \\
\text { comparing the scale of the phase } \\
\text { separation observed to the durability } \\
\text { response of these glasses using the } \\
\text { ASTM-C1285 Product Consistency } \\
\text { Test (PCT) which has been shown to be } \\
\text { extremely sensitive to glass-in-glass } \\
\text { phase separation }\end{array}$ & $\begin{array}{l}\text { Examine data generated by } A . D \text {. } \\
\text { Cozzi and by Jantzen in } 1995^{5} \text { and } \\
\text { determine if a correlation can be } \\
\text { developed between the scale of the } \\
\text { phase separation and the glass } \\
\text { durability. }\end{array}$ & $\begin{array}{l}\text { R.L. Schulz } \\
\text { C.M. Jantzen }\end{array}$ \\
\hline
\end{tabular}

The phase separation discriminator function given in Equation 1 predicts glass compositions to be either homogeneous or phase separated with an associated probability. This is because the discriminator defines the region of phase separation and homogeneity in 14 component space where measurement error in the glass composition and in the determination of whether a glass is truly phase separated or not is difficult. The difficulty often arises due to the small scale of the phase separation, e.g. the smaller the phase separation the more expensive the type of instrumentation necessary for its detection.

The locus of all points defining Equation 1 are shown in two dimensional composition space in Figure 5. The homogeneous glasses which fall in the phase separated ellipse and the phase separated glasses which fall in the homogeneous ellipse are the glasses in which the scale of the phase separation needs to be further investigated in FY00. 


\section{WSRC-TR-99-00110, Revision 0}

\subsection{Management and Quality Assurance}

D.A. Crowley assigned this task to C.M. Jantzen who has the responsibility of overseeing the completion of this work. C.M. Jantzen will be the task leader and is responsible for the proper administration and completion of this task according too $1 \mathrm{Q}, \mathrm{QAP2}-3$, Control of Research and Development Activities ${ }^{28}$ and the SRTC Conduct of Research and Development. 29 Dr. Jantzen will oversee all analytical requirements including any additional chemical composition analyses and all property measurements associated with this task. The final report will be included in this responsibility.

T.K. Snyder and SRTC Quality Assurance Department will provide QA. support.

28 WSRC IQ Quality Assurance Manual, QAP 2-3, Control of Research and Development Activities (1998).

29 Conduct of Research \& Development Savannah River Technology Center (U), WSRC-IM-9700024, Rev. 1, (November 1999). 

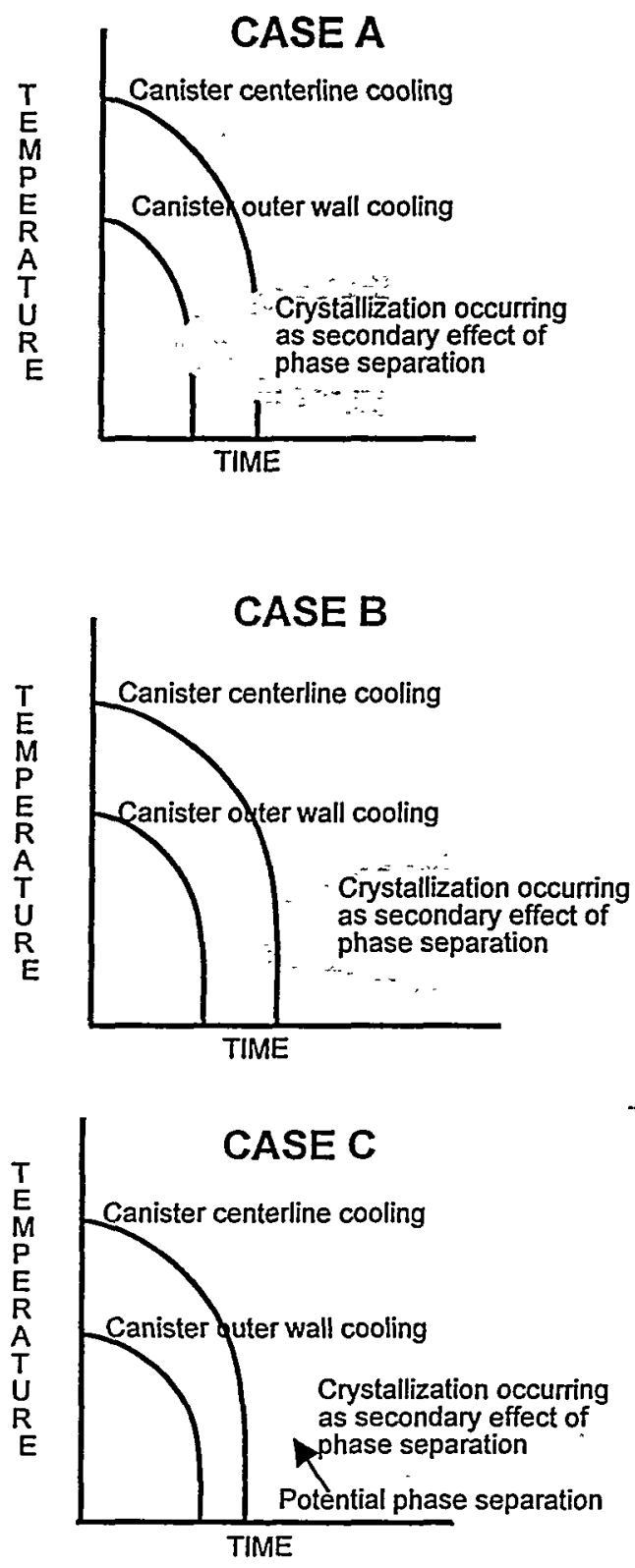

Figure 6. Schematic of the impact of glass cooling (thermal history) on phase separation and crystallization. For case A, if a glass is prone to rapid phase-separation, the entire canister of glass will phase separate. For case B, a glass may phase separate only when slowly cooled as in the center of a canister but not when more rapidly cooled. For case $\mathrm{C}$, a glass that has no tendency to phase separate at any cooling rate. 


\section{DISTRIBUTION:}

Distribution

TFA

R.L. Gilchrist

J.A. Westick

T.M. Brouns

S.N. Schlahlta

B.J. Williams, 8

T.P. Pietrok

STI, 4

E.W. Holtzscheiter

DOE-SR

E.A. Korzun, 703-A

K.L. Hooker, 703-A

WSRC

E.W. Holtzscheiter, 773-A

C.R. Goetzman, 773-A

D.A. Crowley, 773-43A

L.F. Landon, 704-T

C.T. Randall, 704-T

J.R. Harbour, 773-43A

N.E. Bibler, 773-A

D.F. Bickford, 773-43A

C.M. Jantzen, 773-A

K.G. Brown, 704-1T

D.K. Peeler, 773-43A

R.F. Schumacher, 773-43A

M.E. Smith, 773-43A

J.R. Zamecnik, 773-41A

K.A. Howard, 773-43A 